20. Karotkin EH, Masamitsu K, Cashore WJ, Redding RA, Douglas WJ, Stern L, Oh W 1976 Acceleration of fetal lung maturation by aminophylline in pregnant rabbits. Pediatr Res 10:722-724

21. Barrett CT, Sevanian A, Lavin N, Kaplan SA 1976 Role of adenosine 3' $5^{\prime}$ monophosphate in maturation of fetal lungs. Pediatr Res 10:621-625

22. Landers S, Corbet A, Cregan J, Frink J, Rudolph AJ 1984 Effect of aminophylline and caffeine on total and surfactant phospholipid in fetal rabbit lung. Am Rev Respir Dis 130:204-208

23. Butcher RW, Sutherland EW 1962 Adenosine 3' $5^{\prime}$-monophosphate in biological materials. J Biol Chem 237:1244-1250
24. Persson CGA 1984 The pharmacology of antiasthmatic xanthines and the role of adenosine. In: Morley J (ed) Asthma Reviews, Vol I. Academic Press, New York (in press)

25. Bergstrand H 1980 Phosphodiesterase inhibition and theophylline. Eur J Respir Dis 61 (suppl 109):37-44

26. Fain JN, Malbon CC 1979 Regulation of adenylate cyclase by adenosine. Mol Cell Biochem 25:143-169

27. Londos C, Wolff J, Cooper DMF 1981 Adenosine receptors and the regulation of adenylate cyclase. In: Burnstock $G$ (ed) Purinergic Receptors. Chapman and Hall, London, pp 287-323

\title{
ANNOUNCEMENTS
}

\section{International Symposium}

The symposium "Recent Aspects on Diagnosis and Treatment of Lipoprotein Disorders: Impact on Prevention of Atherosclerotic Diseases" will take place in Vienna, Palais Auersperg, August 21-23, 1986. For information contact: Dr. K. Widhelm, Department of Pediatrics, University of Vienna, Währinger Gürtel 18, A-1090 Vienna, Austria.

\section{6th International Postgraduate Course}

"Anesthesia and Intensive Care for Infants and Children", 6th Myron B. Laver International Postgraduate Course, will be held March 14-15, 1986. For details contact: Secretariat, Department of Anesthesia, University of Basel/Kantonsspital, CH-4031 Basel, Switzerland.

\section{Awards in Clinical Research}

Nomination material is now available for The 1986 Lita Annenberg Hazen Awards for Excellence in Clinical Research. The purpose of the awards is to encourage increased participation in clinical research be physicians. Prizes amounting to $\$ 100,000$ are awarded: $\$ 50,000$ (tax free) to an outstanding physician investigator and $\$ 50,000$ for the support of a research fellow(s).

For further information contact: James F. Glenn, M.D., President, The Mount Sinai Medical Center, Chairman, the Lita Annenberg Hazen Awards Program, One Gustave L. Levy Place, New York, NY 10029; or call (212) 650-8832. 